\title{
On Time-reckoning in Old Saami Culture
}

\author{
By Siv NoRLANDER-UNSGAARD
}

\begin{abstract}
Qu'est-ce que le temps?
Le temps est peut-être, parmi les aspects d'une culture, celui qui en caractérise le mieux la nature. Il en est l'incarnation, il est relié à la conception du monde d'une époque, au comportement des individus, à leur conscience, à leur rythme vital, à leurs rapports avec les choses (Gurevich, 1983, 96).
\end{abstract}

Suomen suvi-the Finnish summer

on kaunis-is beautiful

mutta lyhyt-but short.

This quotation ending the first part of Väinö Linna's Crofter Trilogy is also representative of the Danish, Norwegian and Swedish summer, but in particular of the summer in Lapland as well as the other arctic regions. The literary quotation is to be understood in the following sense: Man when young, vigorous and potent has a beautiful life, even though circumstances may not be the best. The underlying aspect has a strong, life-holding character with an erotic flavour that gives us a sad impression because of its sensible awareness of the brevity of Man's powerful period. Here the concept of the individual time aspect in an allegorical sense is quite perceivable.

The concept of time can also be seen from a general point of view. The same word suvi (summer) earlier played an important role in time-reckoning as a part of an old expression in the Saami and Finnish languages concerning a couple of days in the middle or at the end of April. " "[. . . From the 9th to the 15th of April. A. Suwija, D. Kess Idja, 'The week of the Summer nights', E. Suvidja, the day of Tiburtius on the 14th of April [...]. It is worth paying special attention to the form of the word suwija (suvipäivä, on 14th of April, the summerday) which is obviously a loan from the Finnish language [...]"' (Wiklund 1897, 16; cf. Grundström 1950, 47 ff.; Toivonen et al. 1955-81, 1141; cf. Nilsson 1934, 107).

The first impression is confusing. Summer in April is not relevant to the arctic climate. Scheffer says about the Saamis: "[...] As for Spring and

\footnotetext{
${ }^{1}$ The common Lule Saami word for summer is kiessë, kässe (Grundström 1950, 47); cf. Finnish kesä, summer (Toivonen et al. 1955-1981, 187). 
Autumn they know neither, there being so very little space between the extremity of cold in the Winter, and heat in Summer [...]" (Scheffer 1674, 8).

My intention in this paper is to show that time-reckoning in old Saami culture was an orientation towards macrocosmos and microcosmos, conditioned by factors in the ecological environment affecting the course of men's practical activity, and that the concept of the two main seasons-winter and summer-with their subdivisions was the primary basis of time-reckoning. ${ }^{2}$

What kind of sources do we have at our disposal for checking the old Saami concepts of time-reckoning? In this area we have a) a collection of old Saami calendars of wood, bone and horn and the studies of them made by earlier scholars, b) laws, and c) literary notices of various kinds, among them missionary reports. ${ }^{3}$

The way of thinking around the expression of the "week of the Summer nights' in April reminds the scholar well-versed in the sagas of corresponding expressions such as sumarmál, vetrnaetr (summer nights, winter nights) (Nilsson 1960, 82; cf. Lid 1934, 129). The winter night was marked on the calendars on the 14th of October, the day of Calixtus (Lithberg 1921, 152-167). In Lule Saami it was called talvidja (Wiklund 1897, 16; Grundström 1950, 48 f.). ${ }^{4}$

Reckoning time in this way corresponded to the old Icelandic concept of misseri, the summer and winter parts of the year (Beckman 1934, $20 \mathrm{ff}$.). ${ }^{5}$ Kristoffer Sjulsson tells about the same measuring of time from the southern part of Lapland in terms of sjeunjestie (the dark period) and tjuoikestie (the light period) (Pettersson 1979, 87).

Students of the field did not always agree in views and opinions upon this division of the year into two for all Scandinavia, but Sam Owen Jansson, a scholar with great knowledge of the subject writes on time-reckoning as follows:

The division in summer and winter halves of the year, which is constituted in the Icelandic calendar, is most likely to be the original division and belongs to the calendar tradition, common in the whole of Europe. (Jansson 1982, 274.)

Also K. Vilkuna declares openly the same opinion (Vilkuna 1977, 61). Today this view is general among scholars of whom Lithberg is the first to

\footnotetext{
${ }^{2}$ However it is important to realize that "[...] no religion grows out of the ecological, economic or the technical presumptions although the forms do [...]" (Hultkrantz 1973, 146 ff.).

${ }^{3}$ This paper does not intend to cover all the examples. See for example Granlund \& Granlund 1973,182 ff. a covering bibliography.

${ }^{4}$ The corresponding expression is Suvidja, summer night.

${ }^{5}$ See Blöndal et al. $1920-1924,2,550$.
} 
have mentioned it. Almanacs covering only one year began to appear in the late 16th century in Scandinavia (Lithberg 1934, 77; cf. Danver 1943, $14 \mathrm{ff}$.). The first almanac in the Saami language was printed in 1795 and this happened only in Sweden, not in Norway, Russia or Finland (Wiklund 1897, 25). In those days Norway was a part of Denmark and Finland a part of Sweden. The first time an almanac was printed in the Finnish language was in 1705 in $\AA$ bo (Harva 1937, 70). ${ }^{6}$

The printed almanac followed the continental tradition, which is understandable, for printing was invented by Gutenberg in Germany. This tradition is also to be found in the old calendars which preceded the almanac. ${ }^{7}$ It came originally from the Roman Church, which inherited it from Julius Caesar and introduced it in Europe with the Julian calendar. It also brought an oriental influence to Europe (Edsman 1981, 4). This was also the first calendar which was gradually adopted for use in Scandinavia (Jansson 1982, 271).

This was long before the constitution of the national states of DenmarkNorway, Sweden-Finland, which later made use of the same calendars as the Church, but under the name of the civil calendar (Edsman 1981, 4). The Julian calendar tradition is sometimes called 'the old style', for the new Gregorian calendar was introduced in $\mathbf{1 7 5 3}$ in Sweden, while the Academy of Science has been responsible for the almanac since 1749 (Nilsson 1934, 4; Lithberg 1933, 59). These two calendars existed and were used side by side for a long time and people stuck willingly to the old style (Nilsson 1934, 4).

The official calendar tradition is also called 'the learned tradition'. Before the civil calendar appeared, the dioceses in Trondheim (Nidaros), Uppsala and $\AA$ bo (from 1220) were responsible for time-reckoning. They were given great freedom by the Pope, as can be seen from the calendars, where the names of many saints appear at different dates in the three dioceses. The days of Tiburtius and Calixtus were nearly always mentioned, however, and always in the middle of April and October. We can therefore take it for granted that a very old concept of time-reckoning in seasons is concealed behind the names of the two Popes, who meant little to people in Scandinavia and that this concept was valid in all three dioceses (Nilsson 1934, $105 \mathrm{ff}$.).

It is evident that the authorities, particularly the Church and the national

\footnotetext{
${ }^{6}$ Sweden and Finland were separated in 1809 , when Russia took the supremacy over Finland. In compensation Sweden got Norway which was a part of Denmark earlier. This union was dissolved in 1905 and Norway became an independent state. Finland became also independent -in 1917 (Carlsson-Rosén 1979, 448, 488).

${ }^{7}$ About definitions of tradition see Hultkrantz 1960, 229 ff.; Hultkrantz 1973, 14 f.; Mebius 1972, 55.
} 
states, had a common interest in the calendar, for it was a useful instrument for attaining their goals. The Church wanted control over the souls and the national states wanted both taxes and control over the people. The oldest form of taxes was connected with the seasons in the form of the winter and summer taxes. The word summer became an important term among the different taxes and is mentioned in most of our laws. This is even the original meaning of the word calendar in Latin calendarium, which was the name of the account-books in Rome (Liebgott 1973, 9).

In addition to the learned and civil calendar tradition there is a popular one observed in time-reckoning. There is no doubt that this popular tradition is the older one, as it has grown out of local customs. It is amazing how conservative people are; generation after generation do what the elder generation did in matters concerning time-reckoning. Authorities may try to change the rules, but a custom related to the biocosmic rhythm with its change of light and darkness was considered sacred. It gave the biological revival to man's economic conditions in the form of growing plants, hunting and breeding animals. Therefore the marking of such a custom in the calendar was not a suitable object for alteration. ${ }^{8}$

People in Europe used a calendar perpetuum, "an eternal calendar", before and even after the almanac was introduced. It was a kind of device for calculating time, especially holy days, in the manner they were used to. A definition of the word calendar is here required:

By the term 'calendar' we understand the system by which days are named in relation to their place in larger units of time. In this sense the subdivision of the day into hours or other small units is independent of the calendar, while the era or other method by which years are named or numbered is also, as a rule, independent of it. Even the point from which the year is reckoned may be independent, and the Julian calendar has notoriously been used along with many different eras and many different New Year's Days [...] (Fotheringham 1910, 61).

As we have seen above the use of the word calendar has a double function, the one abstract, the other concrete.

The calendars preceding the almanac were made of different materials and could have all kinds of forms such as swords, sticks, wands, rings, books, boards, boxes, clocks, pictures and they could even be fan-shaped. They appeared under different denominations, a common appellation was rimstavar from rime (time-reckoning) and stavar (wands) (Lithberg 1920, 1-27; Lithberg 1934, 77-94).

An English term was Runic calendars, because of the carved sign of the

${ }^{8}$ Examples of the importance of the sun in people's early history see Edsman 1957; Biezais $1972,249$. 
old runic letters. The use of these was in a way complicated and a man was regarded with respect, if he knew how to handle a score or a runic calendar.

The Saami calendars were made of wood, bone or horn and took the shape of plates, lamellae. Ingalill and John Granlund have pointed out that the handy form and the material better suited nomadic conditions than breakable wands. They were made portable (Granlund \& Granlund 1973, 87). The result of their investigation of thirty old Saami calendars was that Saami time-reckoning is of a very old date. It is of the same very old type as the board calendar from Tröndelagen and the 'rimstainar' (time-reckoning stones) from Estonia, previously investigated by Nils Lithberg and Sam Owen Jansson (Granlund \& Granlund 1973, 94).

The calendars of this epoch were earlier valid also for the Scandinavian peninsula. Evidence of their old origin is found in the reckoning of weeks. Lithberg writes about the reckoning of weeks: "[...] in Scandinavia there existed an ancient primitive division of time founded on the revolution of the moon [...]. The basis was the half of a lunation, which resulted in 'fortnights', in 'ny' and 'nedan' (new moon, waning moon) [...]" (Lithberg 1944, 158). The word week is of a very old use, for it existed long before Christianity and therefore cannot be a Christian invention. The week is connected with the phases of the moon (Vilkuna 1957-58, 213).

When the Julian calendar was introduced, the Saamis continued their way of measuring time in weeks, because they were used to having fixed points based on such a time-reckoning. This was the reason why they did not accept the new system of counting in months. On the whole there is no Saami calendar arranged in months (Granlund \& Granlund 1973, 97). When they later adopted months, it was in a system of thirteen months, but the weeks were originally the mainstay of their time-reckoning.

The Granlunds discovered that Saami time-reckoning was dependent on the summer and winter solstices and on the vernal and autumnal equinoxes. The latter ones were the points of time when new work started and the Saamis changed their settlements (Granlund \& Granlund 1973, 97; cf Alstadius 1750, 169). It was at the vernal and the autumnal equinoxes that the durative time of the summer and the durative time of the winter began. These were also times for sacrificing (Mebius 1972, 96 f.). The confusing names of the old calendars: Suvidja (summer night) in the middle of April and Talvidja (winter night) in the middle of October are now quite perceivable to us. (cf. Grundström 1946-54, 1027, 1071).

When were the limits of the seasons fixed in the calendar? In all probability they already appeared in the first official calendar. In the continental calendar tradition we find that Tiburtius and Calixtus were fixed at the same dates as in Scandinavia. Lithberg stresses that the popular tradition of 
these two days has been long alive in the Swedish countryside. He finds no traces in the learned tradition of them (Lithberg 1953, 274).

The Julian calendar was valid in many countries, but the binary division of the year into summer and winter halves is older than Christianity. The word sommar in Swedish (summer) is related to sa'ma in Sanskrit (half year) and has its origin from the reckoning of two seasons among the IndoEuropeans (Hellquist 1980, 1027). This is also the concept of Suvi in the Saami calendar.

The popular Saami concept of time behind the time-reckoning was close to Nature. In a society or a culture where hunting and fishing and breeding animals were the chief occupations, the concepts were influenced by the circumstances surrounding these activities. The environment created the concepts of time (Granlund \& Granlund 1973, 87; cf. Campbell 1982, $81 \mathrm{ff}$. about the importance of the start and the end of a working year or a culture year in an arctic area).

In the northern parts of Sweden as well as in the whole of Finland two Norwegian-Saami expressions are still used as time indicators in everyday language. The first one is skamtida, in the 18th century skamdia, a name for the darkest period of the winter. Lid explains it as derived from skam'stutt' (short) in Latin brevis, and tida (time). It is when the days are short of light. The expression corresponds to bruma in Latin (Lid 1934, 123, 138 note 4). According to linguistic rules the equivalent Finnish word is kaamo(s)aika, aika (time) (Toivonen et al. 1955-81, 134).

The other expression is the Saami word rusjkā, in Finnish: ruska-aika (the red-brown time) for the period when everything turns yellow, red and brown in Nature (1946-54, Grundström 885).

These indications of time are older than our concept of the year. It is therefore incorrect to talk of a 'divided year' (Nilsson 1960, 86 ff.; cf. 'år' (year) in Hellquist 1980, $1422 \mathrm{f}$.). The seasons with their subdivisions were the line in time-reckoning as well as the weeks in pre-Christian society. From this it follows that we have to reconsider the concept of the New Year, unless we are talking of a Nature year, which is the same thing as a Tropic year, the sum of the seasons. In the time-reckoning of the Saamis all seasons (except suvi) have purely Saami names (Wiklund 1897, 5). Usually they talk about eight seasons in all.

The orientation of time from a general point of view was made vertical towards the heavenly bodies-the sun, the moon, the stars; and horizontal towards Nature in form of fauna and flora (cf. Nilsson 1960, 2).

Time indicators took on a sacred aspect and became important to man and his view of the world. For example, in sayings still used, the bear goes into and out of the den in the week around Calixtus and Tiburtius. 
If these two points of time (Calixtus and Tiburtius) are combined we get the period of the winter, which was the hunting period (Dalalagen, see Nilsson 1934, $107 \mathrm{f}$; Grundström 1950, 49). The summer was the growing period and the tree was here a good indicator of time (see James 1961, 11. Preface). The seasons with these indicators always reappear as in a circle, and the ring became the symbol of time (cf. annus in Latin (year) Müller $1982,536 \mathrm{ff}$.). This is a circular concept of time (cf. Gurevich 1969, 48; cf. Benktson 1981, 1).

Time-reckoning in our Western societies of today starts at the birth of Jesus Christ, or what we assume was his birth. As late as the Middle Ages the term märkesår (marking year) was used for a point of time or a period of time, for example, in the event of plague, battle or war (Benediktsson 1981, 161 f.; Liedgren 1981, 162; Vilkuna 1981, 162 f.).

[...] the uniting of the seasons into the year is only a late and incomplete development, $[\ldots]$ the years are not reckoned as members of an era but are distinguished and fixed by concrete events (Nilsson 1960, 86).

Such an event in Saami history was the bear hunt, marked on the drums and on the dress of the hunters. Among the Saamis it took place at the end or the beginning of the winter (cf. Hallowell 1962, $31 \mathrm{ff}$.; "A phenomenon peculiar to the peoples of the far North is that the winter is the time of the festivals [...]" (Nilsson 1960, 339). The hunt and the transport of the heavy bear carcase were possible only during a short period, when snow conditions permitted such an activity. Thus the bear feast marked the end of the winter, or the beginning of it (cf. Bakró-Nagy 1979, 16; cf. Le Roy Ladurie 1979, 337 ff.).

The bear could see and hear everything and was considered to have extraordinarily great powers. For this reason the bear can be seen as a time indicator of the individual life-span. From popular medicine we know about women who used a bear paw as an obstetric help in northern Scandinavia (Gjessing 1953, 250). In the same way Collinder informs us of Saami obstetric tricks and practices: a midwife who "[ . . ] used dead men's bones which were sewn into a black catskin [...]"' (Collinder 1949, 125).

At their betrothal a couple swore fidelity to each other on a bear skin (Düben 1977, 278). Also we hear about bear dances in connections with weddings and on special dates, for example in February and Lent, in the Swedish countryside and in the south of Europe (Edsman 1967-68, 137-146).

Von Düben tells us about a man who counted his ancestry from the number of bears he and his family had killed (Düben 1977, 284; cf. age from aldo [reindeer cow with calf] Drake 1918, 279). 
We know that the bear was regarded as a ferry man for the dead among peoples in the East. Pettersson points out the similarity between the Saami concepts of birth and death. The Saamis give rings as gifts on these occasions (Pettersson 1957, 87; Mebius 1972, $106 \mathrm{ff}$.).

There are many Iron Age finds in the form of bear skins with claws from graves on the island of Gotland and on the east coast of Sweden, which, of course is not a Saami area, but as information it is of great interest (Wigardt \& Petré 1973, 1-51).

The concepts of Man's existence were obviously linked to the bear in Saami culture. He was called 'grandfather' or other fictitious names. Man's existence is the same thing as life-span. The crucial points of the life-span are birth, 'wedding', and death. They all meant a transition from one condition to another and were surrounded by special rites (Gennep 1909, 19-33; cf. Edsman 1963, 1-59). The aspect of time is of the greatest importance within the rites and a common idea in the concept of time was 'to do things in the right time'.?

Vilkuna has shown that it is possible to trace the bear to the old Midsummer, 13.7, and the old Midwinter 13.1 (Vilkuna 1962, 43-83; cf. Edsman $1952,859)$. These two points of time mean a division of the main seasons into two parts, each of thirteen weeks. Vilkuna calls it "the two-parted or four-parted year" (Vilkuna 1962, 43 ff.). It would be more correct to talk about the binary season in relation to what is said above about the year.

Vilkuna's investigation was based on Estonian and Finno-Ugrian materials. To emphasize Finnish influence on Saami calendar terms only from a linguistic point as he, Harva and Grundström do is, in my view, too easy. They neglect the function of the calendar.

The Granlunds comment upon the case is: "As is apparent from the orientation in tabular form of the Sami calendars in picture 5: 5 Harva's, Vilkuna's and Grundström's statements about the Saamis having got their calendar merely from Finland are based on material which is not extensive enough and must therefore be modified [. . .]' (Granlund \& Granlund 1973, 75). Jansson confirms in his criticism that The Granlunds in many connections beat their predecessors who made their observations based on insufficient knowledge of the material and its background (Jansson 1974, 122-133).

To this I have a small objection to make. It is not always possible to reach an opinion about facts combined in tabular form, because the materials is sometimes too widespread in age and local provenance. Can that be the case here? I leave the question open.

\footnotetext{
${ }^{9}$ Time was nothing in itself; it always had a content. See Gurevich 1969, 48; Needham 1965.
} 
The Granlunds have shown the similarities between the Saami and Estonian calendars. (Granlund \& Granlund 1973, 94 ff.) We know that the Saamis migrated around the Gulf of Finland and that the type of calendars they used are common in other hunting cultures. Furthermore, many scholars have pointed out that the concepts in Saami time-reckoning are also related to old Scandinavian time-reckoning. This assumption is no doubt correct. However, the wood and bone calendars are certainly of purely Saami origin for two reasons:

A. The handy form and the material fitting their special conditions (Granlund \& Granlund 1973, 87).

B. The universality in the orientation of time-reckoning is obvious as Nilsson showed as early as 1920 . This view has, however, been neglected by some scholars (Nilsson 1960,2 ). The Saamis may very well have made their own observations just like other peoples.

Seasonal expressions testify to the Granlunds' assumption being correct:

The names of the seasons have pure Saami names: (Lule Saami) tal ${ }^{\mathrm{e}} \mathrm{ve}$ (winter); kitā (spring); kiessē (summer); tjaktja (autumn). Also such compound words for parts of the seasons as kitā-tal ${ }^{\mathrm{e}} \mathrm{ve \overline {e }}$ (spring winter); tjaktja-kiessē (late summer) can be heard (Wiklund 1897, 5).

Why was then the bear such a dominant figure in time-reckoning?

1. The regularity of hibernation made the bear a good indicator of time. The rhythm of hibernation fitted well with the biocosmic rhythm with its change of light and darkness. This established the limits of the main seasons. The bear became the dominant symbol of the entire transition, the passage between winter and summer. This was a macrocosmic orientation. The bear became a mediator between Heaven and Earth. Thus the two different cultures in summer-the growing period-and in winter-the hunting period-depended very much on Man's relation to the bear. What was good came from the bear. In a Skolt Saami myth, for example, it is told that the bear had to draw up the sun every morning (Lundmark 1982, 50 where he is referring to Charuzin).

2. All over the globe time-reckoning has its basis in the biocosmic rhythm, which is experienced as the most important part of Creation everywhere. Some scholars consider it a religious orientation; others do not (see note 9). I shall not deal further with this particular problem in this paper. I shall only remind you about the many myths that tell us how these things were expressed, often in the form of anthropomorphic or theriomorphic stories. So also in old Saami culture. Questions of individual existence were also focused on the biocosmic rhythm-in old Saami culture through 


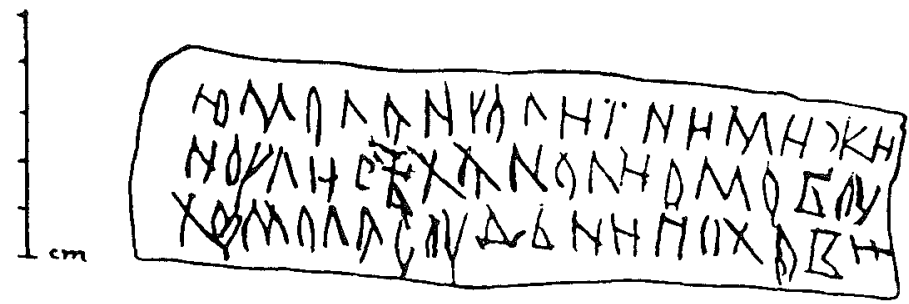

Fig. 1. Published by Artsihovskij and Borkovskij (1963, pp. $120 \mathrm{ff}$.). It is written with cyrillic characters by an unexperienced hand. Jelisejev (1959) has interpreted its contents as a magic charm against lightnings, written in Finnish or one of its dialects. It is the earliest known example of written Finnish. Stratigraphical date: Mid 13th century.

Transliteration:

1. Jumolanuoli 10 nimiži

2. noulisëhanoliomobou

3. ioumola soud'niiohovi
Modern Finnish transcription:

Jumalannuoli kymmenen nimeäsi.

Nuoli, sehän oli oma Bohun.

Jumala "soud" "-ni johtavi.

Translation:

1. "Arrow of God-ten are your names.

2. The arrow-it verily belonged to God.

3. God will guide my fate(?)" (Holthoer 1981, $161 \mathrm{ff}.)^{10}$

the three madderakkas. This is an individual micromacro orientation, the time-reckoning of the individual life-span. We have seen above the bear's importance in the passages between the different stages of the personal life.

3. The appendix, fig. 1, shows how an early man in a Finnish hunting culture (like the Saami) expressed his wonder about the possible connection between the mighty power-God-and his own fate. 'As a magic charm' he used the scroll we are told (see note 10). It means that he used his own

\footnotetext{
${ }^{10}$ Commentary to fig. 1: The identification of the present text as a magic charm is beyond all doubt. In the word jumolanuoli, "arrow of God", I am inclined to see a reminiscence of the Russian word громовержець, "the one who throws thunder/lightnings", an epithet of the pagan god of the Baltians and the Slaves, Perkunas/Perhun. Here, however, a benevolent god is meant and not Perhana, being a modern Finnish word for the devil. The word buo is a genitive form of a loanword from the Russian, where the original word in nominative is Богъ, "God", with a weakly pronounced ending. This loanword is still used in the Carelian dialect. The word soud'ni presents some difficulties of interpretation. I disagree with the accepted opinion, that it refers to the concept "righteous", being a Russian adjective with the singular masculine ending -ni. It seems in fact related to the words соудъ, "judgement" and соудити, "to judge", but is not an adjective but a Russian substantive completed with a Finnish possessive suffix of the 1.p. singular, -ni. This word should consequently be translated as " my judgement", in an extended meaning as "my fate" (Holthoer 1981, 162).
} 
strength to work for a positive connection in his own interest, certainly relating also his own individual time-reckoning.

The importance of the bear in many fields, also in time-reckoning, is still concealed in our cultural heritage as well as in the history of different disciplines $^{11}$. Carl-Martin Edsman has unveiled this to us in his extensive humanist research and he has in this way brought us closer to the views of the world that were significant for earlier generations (see Carl-Martin Edsmans skrifter 1930-1980).

\section{Conclusion}

We have seen above that in old Saami culture the concept of time and timereckoning had the same base, connected with a special content-winter and summer-caused by the biocosmic rhythm. Fauna and flora gave the indications of the coming season. Among these the bear's hibernation was a stable and prominent sign, due to his extreme sensitivity towards the biocosmic rhythm. It may be compared to the sign of the budding tree and the green grass. We can call this an ecological measuring of time, well fitting to the different occupations of a hunter, his settlements and life-style of the main seasons. As the bear was linked to the points of time when light and darkness were shifting, the bear became an important factor in old Saami culture for the orientation on both macrocosmic and microcosmic level. The bear was considered a representative of the mighty powers behind the existence.

\section{Bibliography}

Alstadius, P. 1750. Astrophysica Lapponica. Lärda tidningar 4.6.

Bakró-Nagy, M. Sz. 1979. Die Sprache des Bärenkultes im Obugrischen. Budapest. Beckman, N. 1934. Isländsk och medeltida skandinavisk tideräkning. Nordisk kultur 21. Stockholm.

Benediktsson, J. 1981. Maerkeår. Kulturhistoriskt lexikon för nordisk medeltid 12. København.

Benktson, B.-E. 1981. Det hemlighetsfulla elementet-tiden. Föredrag vid konstnärskonferens på Sigtunastiftelsen 22.11.1981. Göteborg. Off-print.

Biezais, H. 1972. Die himmlische Götterfamilie der alten Letten. (Historia religionum 5.) Uppsala.

Blöndal, S. et al. 1920-1924. Islandsk-Dansk Ordbog 1-2. Reykjavik.

Campbell, A. 1982. Från vildmark till bygd. (Norrländska skrifter 10.) Umeå.

Carlsson, S. \& Rosén, J. 1970. Svensk historia 2. Stockholm.

"Cf. Codex Aboensis is a annotated translation of the manuscript Signum B 172, Kungliga biblioteket, Stockholm. Codex Aboensis is a Festschrift for Kustaa Vilkuna. 
Collinder, B. 1949. The Lapps. New York.

Danver, K. 1943. Folktraditioner kring vårdagjämningen. (Meddelanden från Lunds universitets folkminnesarkiv 1.) Lund.

Drake, S. 1918. Västerbottenslapparna under förra hälften av 1800-talet. (Lapparna och deras land 7.) Uppsala.

Düben, G. v. 1977. Om Lappland och lapparne, företrädesvis de svenske.

Edsman, C.-M. 1952. Fester och helgdagar. Nordisk teologisk uppslagsbok 1.

- 1957. Den dansande solen. Religion och bibel 16. Uppsala.

- 1963. Världsskapelse och livsförnyelse. Ny kyrklig tidskrift 1-2.

- 1967-68. Björnen i folktron. Jaktkamraten 14. Off-print.

- 1981. Tid och kalendrar i Bibelns värld. Ute och hemma julen 1981. Falun. Offprint.

- 1982. Carl-Martin Edsmans skrifter 1930-1980. Åbo.

Fotheringham, J. K. 1910. "Calendar": Introductory. Encyclopaedia of religion and ethics 3. Edinburgh.

Gennep, A. v. 1909. Les rites de passage. Paris

Gjessing, G. 1953. Mennesket og kulturen. Oslo.

Granlund, I. \& Granlund, J. 1973. Lapska ben- och träkalendrar. (Acta Lapponica 19.) Stockholm.

Grundström, H. 1950. Folklig tideräkning i Lule lappmark. Svenska landsmål 73. Uppsala.

Grundström, H. 1946-54. Lulelapsk ordbok-Lulelappisches Wörterbuch. (Skrifter utgivna genom Landsmåls- och Folkminnesarkivet i Uppsala C, 1.) Uppsala.

Gurevich, A. J. 1969. Space and time in the Weltmodell of the old Scandinavian peoples. By A. Ya. Gurevich. Mediaeval Scandinavia 2. Odense.

- 1976. Time as a problem of cultural history. By A. J. Gurevich Cultures and time. Paris.

- 1983. Les catégories de la culture médiévale.

Hallowell, I. 1962. Bear ceremonialism in the northern hemisphere. American anthropologist N. S. 28. New York.

Harva, U. 1937. Volkstümliche Zeitrechnung im eigentlichen Finnland. Folkliv 1.

Hellquist, E. 1980. Svensk etymologisk ordbok 2. Lund.

Holthoer, R. 1981. Birch-bark documents from Novgorod relating Finland and Scandinavia. Figura 19. (Acta universitatis Upsaliensis. N. S. 19.) Uppsala.

Hultkrantz, $\AA$. 1960. International dictionary of regional European ethnology and folklore 1 . Copenhagen.

- 1965. Type of religion in the arctic hunting cultures. Hunting and fishing. Luleå.

- 1973. Metodvägar inom den jämförande religionsforskningen. Stockholm.

- 1981. Belief and worship in native North America. Ed. by C. Vecsey. New York.

James, E. O. 1961. Seasonal feasts and festivals. London.

Jansson, S. O. 1974. Lapska kalendrar. Rig 57.

- 1982. Tideräkning. Kulturhistoriskt lexikon för nordisk medeltid 18. København.

Le Roy Ladurie, E. 1979. Le Carnaval de Romans De la Chandeleur au mercredi des Cendres 1579-80.

Lid, N. 1928. Vegetasjonsgudinne og vårplantar. Festskrift til Rektor J. Quigstad. (Troms $\varnothing$ museums skrifter 2.) Oslo.

- 1934. Den serlege folkelege tidsrekningi i Noreg. Nordisk kultur 21. Stockholm.

Liebgott, N.-K. 1973. Kalendere. København. 
Liedgren, J. 1981. Maerkeår. Kulturhistoriskt lexikon för nordisk medeltid 12. Købenavn.

Lithberg, N. 1920. Runstavens uppkomst. Fataburen 1921.

- 1921. Första vinterdag. Etnologiska studier tillägnade N. E. Hammarstedt 3.3.1921. Stockholm.

- 1933. Almanackan. (Svenska humanistiska förbundet 40.) Stockholm.

- 1934. Kalendariska hjälpmedel. Nordisk kultur 21.

- 1944. Månkalender och veckoräkning. Rig 27.

- 1953. Computus. (Nordiska museets handlingar 29.) ed. S. O. Jansson. Stockholm.

Lundmark, B. 1982. Baei'vi Mánno Nástit. (Acta Bothniensia Occidentalis 5.) Umeå.

Mebius, H. 1972. Sjiele. (Skrifter utg. av Religionshistoriska institutionen i Uppsala (hum.fak.) 9.) Uppsala.

Müller, W. 1982. Raum und Zeit in Sprachen und Kalendern Nordamerikas und Alteuropas: Der römische Kalender. Anthropos 77.

Needham, J. 1965. Time and Eastern man. (Royal Anthropological Institute of Great Britain \& Ireland. Occasional paper 21.) Glasgow.

Nilsson, M. P. 1934. Folklig tideräkning Nordisk Kultur 21 (s. 95-121) ed. M. P. Nilsson Stockholm.

Nilsson, M. P. 1960. Primitive time-reckoning. (Skrifter utg. av Humanistiska Vetenskapssamfundet $i$ Lund.)

Pettersson, O. 1957. Jabmek and Jabmeaimo. Lunds universitets årsskrift N. F. 1, $52,6$.$) Lund.$

Pettersson, O. P. 1979. Kristoffer Sjulssons minnen. Ed. by L. Bäckman \& R. Kjellström. (Acta Lapponica 20.) Lund.

Scheffer, J. 1674. The history of Lapland. Oxford.

Toivonen, Y. H. et al. 1955-81. Suomen kielen etymologinen sanakirja 1-7. (Lexica Societatis Fenno-Ugricae 12, 1-7.) Helsinki.

Wigardt, M. \& Petré, B. 1973. Björnklor $i$ svenska graufynd frän järnåldern. Trebetygsuppsats i arkeologi, Stockholm.

Wiklund, K. B. 1897. Om lapparnas tideräkning. Samfundet för Nordiska museets främjande. Meddelanden 1895-1896. Stockholm.

Vilkuna, K. 1957-1958. Zur ältesten Geschichte der Woche. Folkliv 21-22. Stockholm.

- 1977. Codex Aboensis. Helsinki.

- 1962. Wochenrechnung und Teilung des Jahres in zwei oder vier Teile. FinnischUgrische Forschungen 34. Helsinki.

- 1981. Maerkeår. Kulturhistoriskt lexikon för nordisk medeltid 12. København. 